\title{
Predicting the bond between concrete and reinforcing steel at elevated temperatures
}

\author{
Farhad Aslani* and Bijan Samali \\ Centre for Built Infrastructure Research, School of Civil and Environmental Engineering, \\ University of Technology Sydney, Australia
}

(Received April 20, 2013, Revised October 30, 2013, Accepted November 1, 2013)

\begin{abstract}
Reinforced concrete structures are vulnerable to high temperature conditions such as those during a fire. At elevated temperatures, the mechanical properties of concrete and reinforcing steel as well as the bond between steel rebar and concrete may significantly deteriorate. The changes in the bonding behavior may influence the flexibility or the moment capacity of the reinforced concrete structures. The bond strength degradation is required for structural design of fire safety and structural repair after fire. However, the investigation of bonding between rebar and concrete at elevated temperatures is quite difficult in practice. In this study, bond constitutive relationships are developed for normal and high-strength concrete (NSC and HSC) subjected to fire, with the intention of providing efficient modeling and to specify the fireperformance criteria for concrete structures exposed to fire. They are developed for the following purposes at high temperatures: normal and high compressive strength with different type of aggregates, bond strength with different types of embedment length and cooling regimes, bond strength versus to compressive strength with different types of embedment length, and bond stress-slip curve. The proposed relationships at elevated temperature are compared with experimental results.
\end{abstract}

Keywords: constitutive relationships; concrete; high temperatures; compressive strength; bond strength; bond stress-slip

\section{Introduction}

The exposure of reinforced concrete (RC) structural elements to high temperatures during an aggressive fire leads to significant losses in its structural capacity due to the reduction in the strength of the concrete, possible plastic deformation of embedded steel and most importantly loss of bond between reinforcing steel and concrete. During the past few decades, many researchers have studied the effect of elevated temperature on the residual bond strength and the bond-slip relationship with respect to various parameters, such as the diameter of the rebars, the type of the rebars, the concrete cover, the heating condition and the heating duration.

Whereas the bond between concrete and steel at room temperature was the subject of early and intensive investigation for the high-temperature range there are limited experimental results available. One of the earliest works have been done by Kasami et al. (1975), tests on large number

*Corresponding author, Ph.D., E-mail: Farhad.Aslani@uts.edu.au 
of specimens (120 specimens comprising four different concrete mixes made with ordinary Portland cement and river gravel) containing embedded plain round steel bars were performed. At an age of 90 days the specimens were slowly heated (at a rate of $10^{\circ} \mathrm{C} / \mathrm{h}$, to a maximum temperature of $300^{\circ} \mathrm{C}$ ) and then held at this temperature for 90 days. Next, they were slowly cooled $\left(10^{\circ} \mathrm{C} / \mathrm{h}\right)$ and tested when cool. In each case, the bond stress was determined at which the slip at the non-loaded end was $0.025 \mathrm{~mm}$. A significant decrease of bond strength with increasing temperatures was observed. The residual bond strength after cooling from $300^{\circ} \mathrm{C}$ was about $50 \%$ of its original value before heating.

Another earliest investigation was performed by Milovanov and Salmano (1954). Normalweight concrete prisms $(140 \times 140 \times 300 \mathrm{~mm})$ made with Portland cement and river gravel was tested. Plain round bars and ribbed bars of $20 \mathrm{~mm}$ diameter were embedded in these specimens. The latter were heated to $100,250,350$ and $450^{\circ} \mathrm{C}$ and then allowed to cool, after which they were tested. For each of these temperatures, three tests were performed. Testing comprised pull-out tests, in which the slip occurring at the loaded and at the non-loaded end of the specimen was recorded. After drying at $110^{\circ} \mathrm{C}$, this specimen was tested at a maximum temperature of $250^{\circ} \mathrm{C}$; it was found that the bond of ribbed steels in the hot condition was substantially better than when subsequently cooled. A severe decrease of bond strength of plain round bars was observed at a comparatively small temperature increase. A comparable loss of bond strength of ribbed bars occurs only at temperatures above $400^{\circ} \mathrm{C}$. This finding is not in agreement with Kasami et al. (1975)'s results.

Twenty $150 \times 150 \times 450 \mathrm{~mm}$ prisms with stirrup reinforcement were tested by Reichel (1978). These prisms were heated to various temperatures in accordance with the standard timetemperature curve, allowed them to cool, and then performed pull-out tests. The diameter of the bars was $14 \mathrm{~mm}$, the embedment length was $300 \mathrm{~mm}$, and the concrete was of two quality classes (B17 and B33). Portland cement and mixed aggregate comprising 60\% river gravel and 40\% crushed granite were used. The bond strengths were measured after cooling for $24 \mathrm{~h}$.

Diederichs and Schneider (1981) reported that bond strength depends not only upon the temperature level, but also upon the test procedure and the shape of the bar. In 1982, the work by Hertz (1982) on bond between concrete and plain or deformed bars of different sizes revealed that the diameter of the rebars had little effect on the loss in bond strength due to temperature rise to $500^{\circ} \mathrm{C}$. Royles and Morley $(1982,1983)$ studied the effect of heating to high temperature of up to $720^{\circ} \mathrm{C}$ on the bond strength of pullout specimens prepared at different concrete covers, and subjected to load cycling. They concluded that pullout specimens prepared at smaller concrete covers showed greater reduction in bond strength, and that the cyclic loading of pre-heated specimens had reduced further their bond strength.

\section{Research significance}

Although many experiments in this field have been conducted, the results have mostly been reported in forms of the statistical models or the percentages of bond strength reduction without a thorough understanding of the mechanics behind the changing bond-slip behavior of reinforced concrete elements under thermal loads. Moreover, the developed functions for the residual bond strength can accurately predict only the cases similar to the experimental studies.

Mechanical models are, therefore, essential to understand the mechanism of bonding as well as to predict the residual bond strength for reinforced concrete under high-temperature conditions. In 
Table 1 Experimental results database properties

\begin{tabular}{|c|c|c|c|c|c|c|}
\hline Reference & Cement type & $\begin{array}{l}\text { Aggregate } \\
\text { type }\end{array}$ & $\begin{array}{l}\text { Compressive } \\
\text { Specimen type }\end{array}$ & $\begin{array}{l}\text { Heating } \\
\text { rate }\end{array}$ & $\begin{array}{l}\text { Bar diameter } \\
(\mathrm{mm})\end{array}$ & $\begin{array}{l}\text { Embedment } \\
\text { length }(\mathrm{mm})\end{array}$ \\
\hline $\begin{array}{l}\text { Diederichs and } \\
\text { Schneider (1981) }\end{array}$ & Portland & siliceous & Cube $(100 \mathrm{~mm})$ & $1{ }^{\circ} \mathrm{C} / \mathrm{min}$ & 20 & 80 \\
\hline Hertz (1982) & Portland & $\begin{array}{l}\text { Mixture of } \\
\text { quartz, } \\
\text { granite and } \\
\text { limestone }\end{array}$ & - & $1^{\circ} \mathrm{C} / \mathrm{min}$ & $\begin{array}{c}25 \\
16 \\
12 \\
8\end{array}$ & $\begin{array}{l}150 \\
150 \\
150 \\
150\end{array}$ \\
\hline $\begin{array}{c}\text { Royles and } \\
\text { Morley (1983) }\end{array}$ & Portland & siliceous & $\begin{array}{l}\text { Cylindrical (150 } \\
\times 300 \mathrm{~mm})\end{array}$ & $2{ }^{\circ} \mathrm{C} / \mathrm{min}$ & $\begin{array}{l}16 \\
16 \\
16 \\
16 \\
16\end{array}$ & $\begin{array}{l}32 \\
32 \\
32 \\
32 \\
32\end{array}$ \\
\hline $\begin{array}{l}\text { Ahmed et al. } \\
\text { (1992) }\end{array}$ & Portland & limestone & Cube $(150 \mathrm{~mm})$ & $1^{\circ} \mathrm{C} / \mathrm{min}$ & 12 & 150 \\
\hline $\begin{array}{c}\text { Haddad and } \\
\text { Shannis (2004) }\end{array}$ & $\begin{array}{l}\text { Portland } \\
\text { limestone } \\
\text { cement }\end{array}$ & $\begin{array}{c}\text { crushed } \\
\text { coarse } \\
\text { limestone } \\
\text { and siliceous } \\
\text { sand }\end{array}$ & Cube $(100 \mathrm{~mm})$ & $20^{\circ} \mathrm{C} / \mathrm{min}$ & 18 & 32 \\
\hline $\begin{array}{l}\text { Haddad et al. } \\
\qquad(2008)\end{array}$ & Portland & $\begin{array}{c}\text { crushed } \\
\text { coarse } \\
\text { limestone } \\
\text { and siliceous } \\
\text { sand }\end{array}$ & Cube $(100 \mathrm{~mm})$ & - & $\begin{array}{l}\text { deformed steel } \\
\text { rebars of } \\
\text { diameters } \\
(20 \mathrm{~mm}) \\
\text { deformed steel } \\
\text { rebars of } \\
\text { diameters } \\
(10 \mathrm{~mm}) \\
\text { smooth steel } \\
\text { rebars of } \\
\text { liameters }(8 \mathrm{~mm})\end{array}$ & 150 \\
\hline $\begin{array}{l}\text { Bingöl and Gül } \\
\text { (2009) }\end{array}$ & Portland & siliceous & - & $\begin{array}{c}12-20 \\
{ }^{\circ} \mathrm{C} / \mathrm{min}\end{array}$ & 8 & $\begin{array}{c}60,100 \text { and } \\
160\end{array}$ \\
\hline
\end{tabular}

this study, constitutive relationships are developed for normal and high-strength concrete (NSC and HSC) subjected to fire, with the intention of providing efficient modeling and to specify the fire-performance criteria for concrete structures exposed to fire. They are developed for the following purposes at high temperatures: normal and high compressive strength with different type of aggregates, bond strength with different types of embedment length and cooling regimes, bond strength versus to compressive strength with different types of embedment length, and bond stressslip curve.

\section{Database of experimental results}

An experimental results database from various published investigations is an effective tool for studying the applicability of the various high temperature behaviours for SFRC. To apply the 
Table 2 Experimental results database properties (continued)

\begin{tabular}{|c|c|c|c|c|c|c|}
\hline Reference & $\begin{array}{l}\text { Cover / } \\
\text { Bar } \\
\text { diameter }\end{array}$ & $\begin{array}{l}\text { Maximum } \\
\text { exposed } \\
\text { temperature } \\
\left({ }^{\circ} \mathrm{C}\right)\end{array}$ & $\begin{array}{l}\text { Compressive } \\
\text { strength range } \\
(\mathrm{MPa})\end{array}$ & Bar type & Pull-out specimen type & $\begin{array}{l}\text { Cooling } \\
\text { condition }\end{array}$ \\
\hline $\begin{array}{l}\text { Diederichs and } \\
\text { Schneider (1981) }\end{array}$ & 4.88 & 500 & $48.0-60.9$ & deformed & $\begin{array}{c}\text { cylindrical specimens } \\
\text { (80 mm diameter and } \\
300 \mathrm{~mm} \text { length) }\end{array}$ & Air \\
\hline \multirow{4}{*}{ Hertz (1982) } & 2.50 & 800 & 20.0 & Danish & \multirow{4}{*}{ cylindrical specimens } & \multirow{4}{*}{ Air } \\
\hline & 4.18 & 800 & 20.0 & deformed, & & \\
\hline & 5.75 & 800 & 20.0 & Danish & & \\
\hline & 8.875 & 800 & 20.0 & $\begin{array}{l}\text { Tentor, } \\
\text { Plain }\end{array}$ & & \\
\hline \multirow{5}{*}{$\begin{array}{l}\text { Royles and Morley } \\
\qquad(1983)\end{array}$} & 1.56 & 750 & 35.0 & \multirow{5}{*}{$\begin{array}{l}\text { plain and } \\
\text { deformed }\end{array}$} & \multirow{5}{*}{$\begin{array}{c}\text { cylindrical specimens } \\
\text { (with } 3.77 \mathrm{MPa} \text { pre- } \\
\text { stress) }\end{array}$} & \multirow{5}{*}{ Air } \\
\hline & 2.00 & 750 & 35.0 & & & \\
\hline & 2.88 & 750 & 35.0 & & & \\
\hline & 3.44 & 750 & 35.0 & & & \\
\hline & 3.44 & 750 & 35.0 & & & \\
\hline $\begin{array}{l}\text { Ahmed } \text { et al. } \\
\text { (1992) }\end{array}$ & 5.75 & 600 & - & deformed & $\begin{array}{l}\text { square concrete prisms } \\
(150 \mathrm{~m} \times 150 \times 200 \mathrm{~mm})\end{array}$ & $\begin{array}{l}\text { Air and } \\
\text { water }\end{array}$ \\
\hline \multirow{2}{*}{$\begin{array}{c}\text { Haddad and } \\
\text { Shannis (2004) }\end{array}$} & 1.78 & \multirow{2}{*}{800} & \multirow{2}{*}{73.15} & \multirow{2}{*}{ deformed } & \multirow{2}{*}{$\begin{array}{l}\text { two diameters of } 82, \\
\text { and } 100 \mathrm{~mm} \text { and a } \\
\text { length of } 150 \mathrm{~mm}\end{array}$} & \multirow{2}{*}{ Air } \\
\hline & 2.28 & & & & & \\
\hline \multirow{3}{*}{$\begin{array}{l}\text { Haddad et al. } \\
\qquad(2008)\end{array}$} & 2.00 & \multirow{3}{*}{700} & \multirow{3}{*}{77.30} & \multirow{3}{*}{$\begin{array}{l}\text { plain and } \\
\text { deformed }\end{array}$} & \multirow{3}{*}{$\begin{array}{l}\text { square concrete prisms } \\
(100 \mathrm{~m} \times 100 \times 200 \mathrm{~mm})\end{array}$} & \multirow{3}{*}{ Air } \\
\hline & 4.00 & & & & & \\
\hline & 5.00 & & & & & \\
\hline $\begin{array}{l}\text { Bingöl and Gül } \\
\text { (2009) }\end{array}$ & 5.75 & 700 & 20 and 35 & deformed & $\begin{array}{l}100 \mathrm{~mm} \text { diameter and } \\
200 \mathrm{~mm} \text { height } \\
\text { cylinders }\end{array}$ & $\begin{array}{l}\text { Air and } \\
\text { water }\end{array}$ \\
\hline
\end{tabular}

models to a particular concrete mixture accurately, it is necessary to use only investigations that are sufficiently consistent with the applied testing methodology. The SFRC experimental results included in the database were gathered mainly from papers presented at various published articles. The database includes information regarding the composition of the mixtures, fresh properties of SFRC, testing methodology, and conditions. Thermal characteristics have not been investigated as much as the other aspects of SFRCC.

Tables 1-2 include general information about the experimental tests, such as cement type, aggregate type, compressive specimen type, heating rate, bar diameter, embedment length, cover / bar diameter, maximum exposed temperature, compressive strength range, bar type, pull-out specimen type, and cooling condition. Table 1 shows that general type of cement that is used in the most of researches is Ordinary Portland Cement. Also, common aggregates that were used in the database are siliceous and crushed limestone. Moreover, the cube specimen is used for measuring of compressive strength, heating rate range is between $1{ }^{\circ} \mathrm{C} / \mathrm{min}$ to $20^{\circ} \mathrm{C} / \mathrm{min}$, and embedment length (ld) is varied between $30 \mathrm{~mm}$ to $160 \mathrm{~mm}$. Table 2 indicates compressive strength of used concrete in the tests are between 20 to $78 \mathrm{MPa}$, deformed rebar is common used type, common pull-out specimen type is cylindrical, and air and water are the common cooling procedure. The temperature range that is considered in this study is between $100^{\circ} \mathrm{C}$ to $800^{\circ} \mathrm{C}$. 


\section{Compressive strength of NSC and HSC at elevated temperatures}

The residual compressive behavior of NSC has been under investigation since the early 1960s (see the contributions by Zoldners, Dougill, Harmathy, Crook, Kasami et al., Schneider and Diederiches, all quoted in Schneider, 1985). Attention has been focused mostly on the compressive strength (the strength at room temperature after a specimen has been heated to a test temperature and subsequently cooled) as such, on the residual strain and on strength recovery with time (Fib Bulletin 46 2008). In this study, the relationships proposed for the compressive strength of normal, high-strength (siliceous aggregate), calcareous and lightweight aggregate concrete at elevated temperature are based on regression analyses on existing experimental data with the results expressed as Eqs. (1)-(5) (Aslani and Samali 2013a, b, c).

The main aim of regression analyses is considering the changeable experimental compressive strength of normal strength concrete (NSC), high strength concrete (HSC), calcareous aggregate concrete (CAC), and lightweight aggregate concrete (LAC) behaviors at different elevated temperatures and developing the rational and simple relationships that can fit well with experimental data. These proposed relationships are compared separately with test results, as shown in Figs. 1-5.

Normal strength concrete

$$
f_{c T}^{\prime}=f_{c}^{\prime}\left\{\begin{array}{cl}
1.012-0.0005 T \leq 1.0 & 20^{\circ} \mathrm{C} \leq T \leq 100^{\circ} \mathrm{C} \\
0.985+0.0002 T-2.235 \times 10^{-6} T^{2}+8 \times 10^{-10} T^{3} & 100^{\circ} \mathrm{C}<T \leq 800^{\circ} \mathrm{C} \\
0.44-0.0004 T & 900^{\circ} \mathrm{C} \leq T \leq 1000^{\circ} \mathrm{C} \\
0 & T>1000^{\circ} \mathrm{C}
\end{array}\right\}
$$

High strength concrete (Siliceous aggregate)

$$
\begin{gathered}
f_{c T}^{\prime}=f_{c}^{\prime}\left(\begin{array}{cl}
1.01-0.00068 T \leq 1.0 & 20^{\circ} \mathrm{C} \leq T \leq 200^{\circ} \mathrm{C} \\
0.935+0.00026 T-2.13 \times 10^{-6} T^{2}+8 \times 10^{-10} T^{3} & 200^{\circ} \mathrm{C}<T \leq 400^{\circ} \mathrm{C} \\
0.90+0.0002 T-2.13 \times 10^{-6} T^{2}+8 \times 10^{-10} T^{3} & 400^{\circ} \mathrm{C}<T \leq 800^{\circ} \mathrm{C} \\
0.44-0.0004 T & 900^{\circ} \mathrm{C} \leq T \leq 1000^{\circ} \mathrm{C} \\
0 & T>1000^{\circ} \mathrm{C}
\end{array}\right\} 55.2 \mathrm{MPa} \leq f_{c}^{\prime} \leq 80 \mathrm{MPa} \\
f_{c T}^{\prime}=f_{c}^{\prime}\left\{1+0.00014 T-1.6 \times 10^{-6} T^{2} \quad 20^{\circ} \mathrm{C} \leq T \leq 800^{\circ} \mathrm{C}\right\} \quad 80 \mathrm{MPa}<f_{c}^{\prime} \leq 110 \mathrm{MPa}
\end{gathered}
$$

Calcareous aggregate concrete

$$
f_{c T}^{\prime}=f_{c}^{\prime}\left\{\begin{array}{cc}
1.01-0.0006 T \leq 1.0 & 20^{\circ} C \leq T \leq 200^{\circ} C \\
1.0565+0.0017 T+5 \times 10^{-6} T^{2}-5 \times 10^{-9} T^{3} & 200^{\circ} C<T \leq 900^{\circ} C \\
0 & 900^{\circ} C<T
\end{array}\right\}
$$

Lightweight aggregate concrete

$$
f_{c T}^{\prime}=f_{c}^{\prime}\left\{\begin{array}{cc}
1.01-0.00037 T \leq 1.0 & 20^{\circ} C \leq T \leq 300^{\circ} C \\
1.0491-0.00036 T+10^{-6} T^{2}-2 \times 10^{-9} T^{3} & 300^{\circ} C<T \leq 900^{\circ} C \\
0 & T \geq 1000^{\circ} C
\end{array}\right\}
$$

Figs. 1-3 show the variation of compressive strength test results with temperature for NSC and 


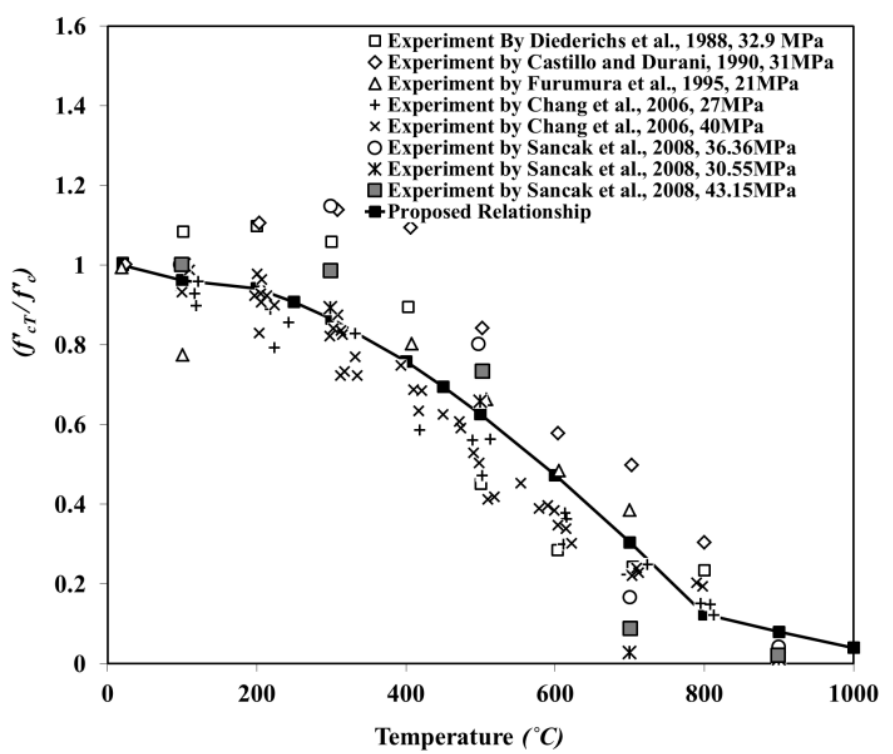

Fig. 1 Comparison between compressive strength of NSC at elevated temperature with experimental data

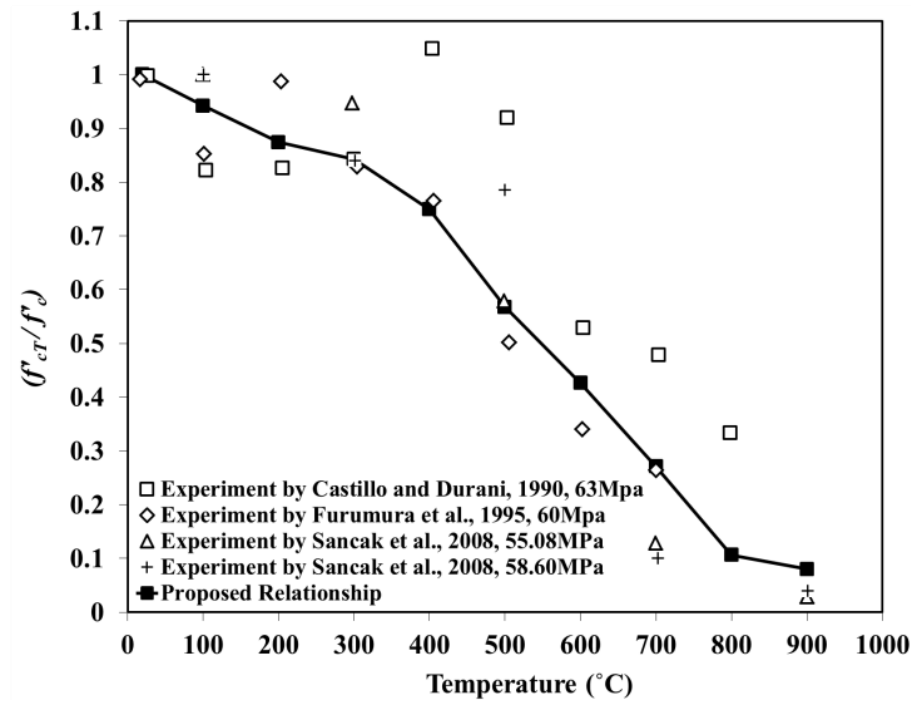

Fig. 2 Comparison between compressive strength of high strength siliceous aggregate concrete $(55.2-80 \mathrm{MPa})$ at elevated temperature with experimental data

HSC. Fig. 1 makes comparison the proposed relationship for NSC at different temperatures against published unstressed experimental test results (unstressed tests: the specimen is heated, without preload, at a constant rate to the target temperature, which is maintained until a thermal steady state is achieved) (Diederichs et al. 1988, Castillo and Durrani 1990, Furumura et al. 1995, Chang et al. 2006, Sancak et al. 2008). NSC typically loses 10-20\% of its original compressive strength when heated to $300^{\circ} \mathrm{C}$, and $60-75 \%$ at $600^{\circ} \mathrm{C}$. Figs. 2-3 show comparisons the proposed relationship for high strength siliceous aggregate concrete, i.e., 55.2-80 $\mathrm{MPa}$ and 80-110 $\mathrm{MPa}$, at 


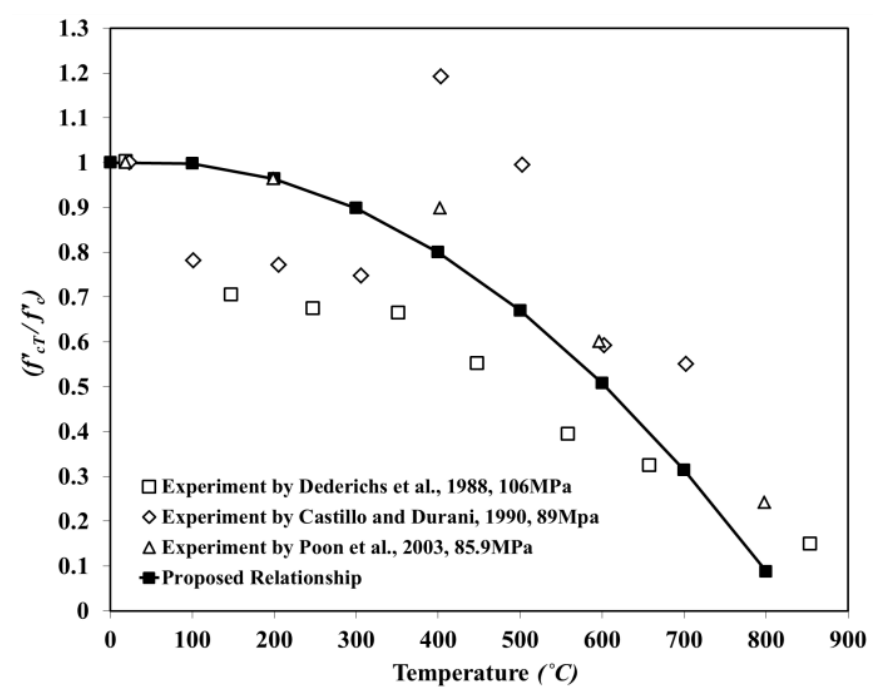

Fig. 3 Comparison between compressive strength of high strength siliceous aggregate concrete (80-110 MPa) at elevated temperature with experimental data

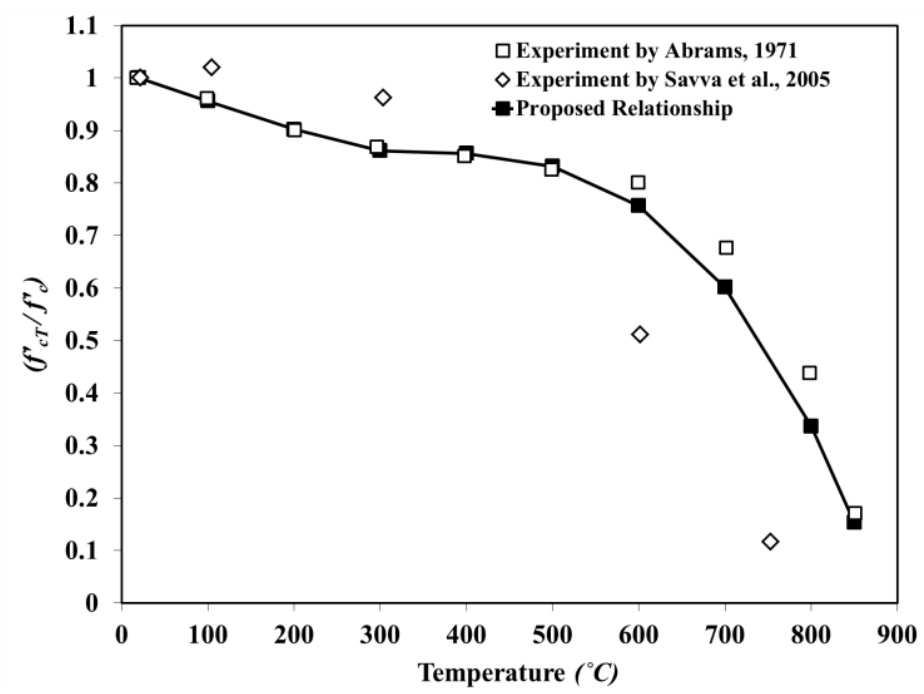

Fig. 4 Comparison between compressive strength of calcareous aggregate concrete at elevated temperature with experimental data

different temperatures against published unstressed experimental results (Diederichs et al. 1988, Castillo and Durrani 1990, Furumura et al. 1995, Sancak et al. 2008, Poon et al. 2003). Higher rates of original strength loss, as much as $40 \%$, were observed for HSC at temperatures up to $450^{\circ} \mathrm{C}$. Fig. 4 shows a comparison the proposed relationship for normal-strength calcareous aggregate concrete against the unstressed experimental results reported by Abrams (1971) and Savva et al. (2005). The proposed relationship agrees with the test results fairly well. Fig. 5 shows a comparison the relationship proposed here for normal-strength lightweight aggregate concrete and the unstressed experimental results reported by Abrams (1971), Savva et al. (2005). The 


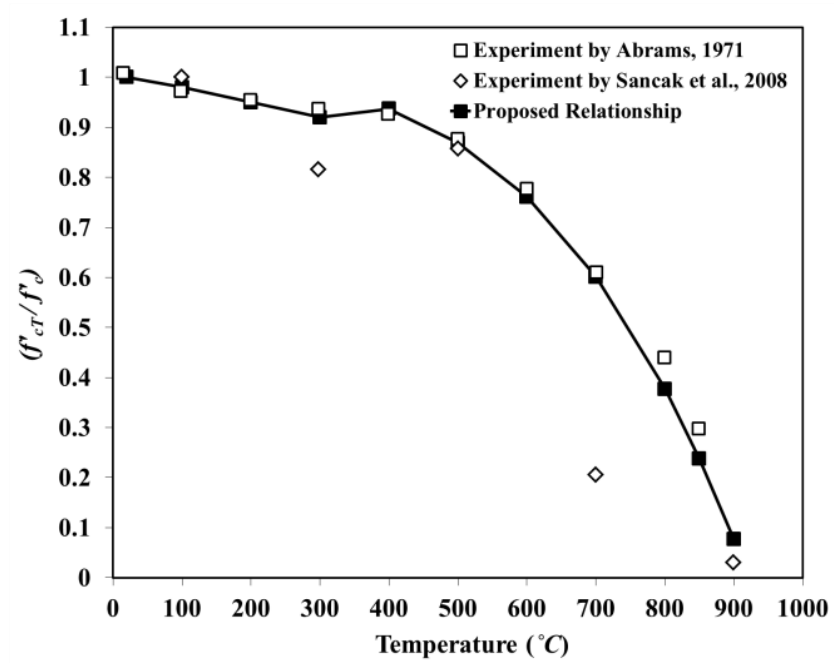

Fig. 5 Comparison between compressive strength of lightweight aggregate concrete at elevated temperature with experimental data

proposed relationships fit the experimental results well in comparison with others. These relationships are calibrated with the experimental results in another author paper (Aslani and Bastami 2011).

\section{Bond strength at ambient temperature}

Many researchers have examined relationships between pull-out load and compressive strength. All studies in this area have shown that the bond strength (stress) increases with the compressive strength of concrete (Malhotra 1975, Richards 1977, Skramtajew 1983, Stone and Carino 1983, Stone and Giza 1985). In this regard, ACI 318 (2008) proposes that the bond strength is linearly proportional to. It can be easily concluded from the earlier literature that the average bond stress reduces as the embedment length increases due to the nonlinear stress distribution that exists between the rebar and the concrete. Another conclusion is that average bond stress decreases with larger rebar diameters. Different explanations exist for the decrease in bond stress due to the larger rebar diameters (Ichinose et al. 2004). In this study, the relationships proposed for the conventional concrete are based on regression analyses using existing experimental data (proposed by Aslani and Nejaid 2012), with the results expressed as Eqs. (6)-(7).

Eq. (6) considers plain rebar bond strength, whereas Eq. (7) considers deformed rebar bond strength, respectively. In these equations the influences of concrete cover, bar diameter, embedment length, and compressive strength (at the curing age) parameters are considered.

$$
\begin{aligned}
& \tau_{\text {max } x 20}=\left(0.7\left(\frac{c}{d_{b}}\right)^{0.6}+4\left(\frac{d_{b}}{l_{d}}\right)\right)\left(f_{c}^{\prime}\right)^{0.23} \\
& \tau_{\max , 20}=\left(0.679\left(\frac{c}{d_{b}}\right)^{0.6}+3.88\left(\frac{d_{b}}{l_{d}}\right)\right)\left(f_{c}^{\prime}\right)^{0.55}
\end{aligned}
$$


where $d_{b}$ is the diameter of the steel bar, $l_{d}$ is the embedded length of the steel bar, $f^{\prime} c$ is the compressive strength of the concrete, and $c$ is the concrete cover. Proposed bond strength models are related to compressive strength. Further, because the compressive strength test types of specimens in the database are different, the $f_{c}^{\prime}$ values should be corrected. In this study, the most used type of compressive strength test in the database (i.e., $100 \mathrm{~mm} \times 200 \mathrm{~mm}$ cylindrical) is considered as main and other types of test results (i.e., $150 \mathrm{~mm} \times 300 \mathrm{~mm}$ cylindrical and $150 \mathrm{~mm}$ cube) must convert to it. Yi et al. (2006) reported that the relationship between $100 \mathrm{~mm} \times 200 \mathrm{~mm}$ cylindrical with $150 \mathrm{~mm}$ cube was: $f_{c y(100 \times 200)}^{\prime}=\left(f_{c u(150)}^{\prime}-8.86\right) / 0.85$. Also, Carrasquillo et al. (1981) stated that the average ratio of compressive strength of $150 \mathrm{~mm} \times 300 \mathrm{~mm}$ to $100 \mathrm{~mm} \times$ $200 \mathrm{~mm}$ cylinders was 0.9 , regardless of strength and test age.

\section{Bond strength at elevated temperature}

Investigations into the bond strength between the concrete and reinforcing steel at room temperature have been carried out over many years. Comparatively few experiments have, however, been carried out to investigate the effects of high temperatures on the bond characteristics. Bazant and Kaplan (1996) summarized some tested results and some broad conclusions were drawn as:

- Bond strength is reduced as temperature increases and the reduction rate is greater compared to concrete strengths.

- The percentage reduction of bond strength for ribbed bars at elevated temperatures is generally less than for plain round steel bars.

- Differences in the diameters of plain bars and deformed bars had little effect on the strength reduction of the bond.

- The experimental procedure used affects the results of bond tests at high temperatures.

- The type of aggregate in the concrete affects the bond strength at elevated temperatures.

- The smaller the concrete cover, the greater is the reduction in bond strength.

Due to the complexity of bond characterization at elevated temperatures, as first order approximation, simplified models are proposed here to calculate the bond strengths of deformed bars at elevated temperatures. For ribbed bars, the bond strength reduction at high temperatures can be represented as Eqs. (8)-(9), for air and water cooling procedures and embedment length between $30 \mathrm{~mm}$ to $160 \mathrm{~mm}$. In the Eqs. (8)-(9), $\tau_{\max , 20}$ parameter can be calculated by using Eqs. (6)-(7) that is covered plain and deformed rebar.

Air

$$
\frac{\tau_{\max , T}}{\tau_{\max , 20}}=\left\{\begin{array}{cc}
1-0.00033 \times \mathrm{T}-1 \times 10^{-6} \times \mathrm{T}^{2} & 30 \mathrm{~mm}<l_{d} \leq 100 \mathrm{~mm} \\
1-0.00082 \times \mathrm{T}-2 \times 10^{-7} \times \mathrm{T}^{2} & 100 \mathrm{~mm}<l_{d} \leq 160 \mathrm{~mm} \\
1-0.00060 \times \mathrm{T}-7 \times 10^{-7} \times \mathrm{T}^{2} & 30 \mathrm{~mm} \leq l_{d} \leq 160 \mathrm{~mm}
\end{array}\right\} \quad 20^{\circ} \mathrm{C} \leq \mathrm{T} \leq 800^{\circ} \mathrm{C}
$$

Water

$$
\frac{\tau_{\max , T}}{\tau_{\max , 20}}=\left\{\begin{array}{cc}
1-0.00015 \times \mathrm{T}-1 \times 10^{-6} \times \mathrm{T}^{2} & 30 \mathrm{~mm}<l_{d} \leq 100 \mathrm{~mm} \\
1-0.00090 \times \mathrm{T}-2 \times 10^{-7} \times \mathrm{T}^{2} & 100 \mathrm{~mm}<l_{d} \leq 160 \mathrm{~mm} \\
1-0.00047 \times \mathrm{T}-7 \times 10^{-7} \times \mathrm{T}^{2} & 30 \mathrm{~mm} \leq l_{d} \leq 160 \mathrm{~mm}
\end{array}\right\} \quad 20^{\circ} \mathrm{C} \leq T \leq 800^{\circ} \mathrm{C}
$$




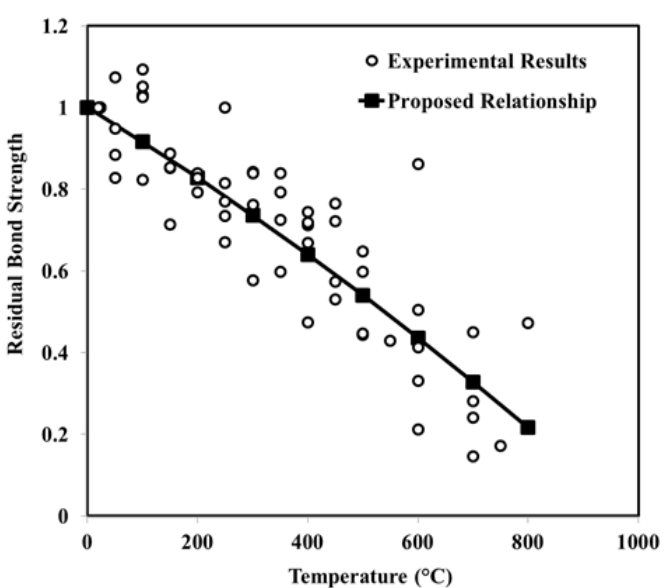

(a)

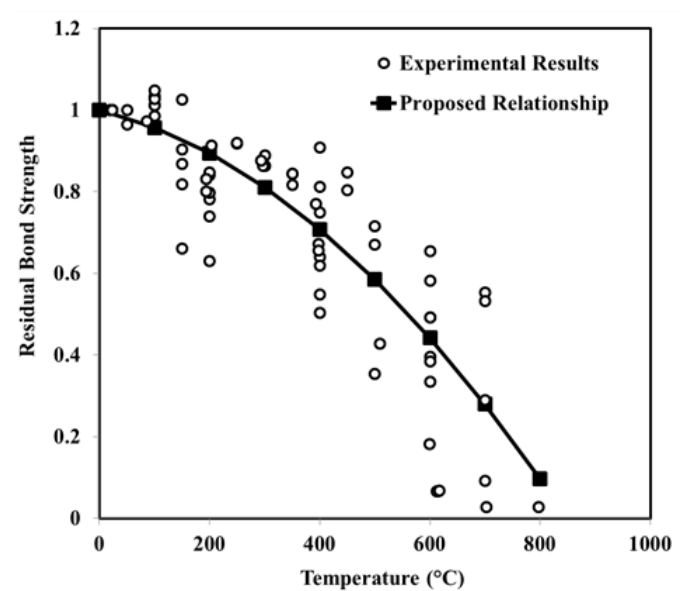

(b)

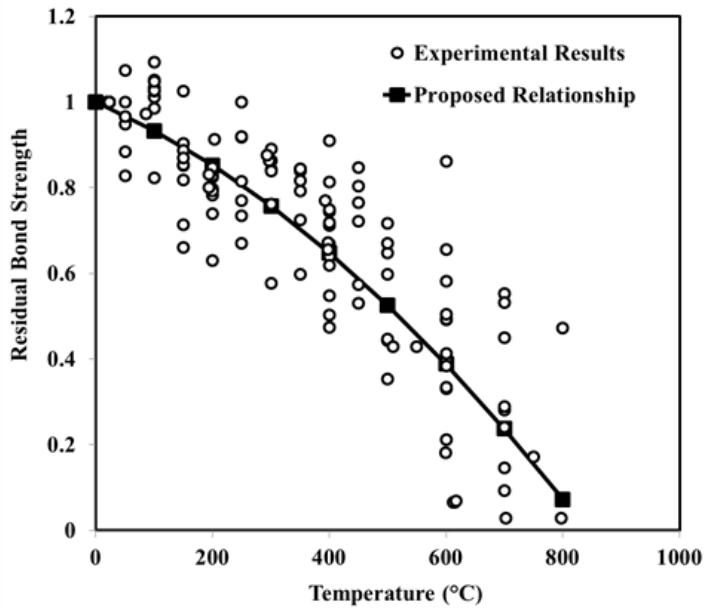

(c)

Fig. 6 Comparison between the air cooling condition proposed relationship for bond strength at different temperatures against experimental results database with (a) $30 \mathrm{~mm}<l_{d} \leq 100 \mathrm{~mm}$, (b) $100 \mathrm{~mm}<l_{d} \leq 160 \mathrm{~mm}$, and (c) $30 \mathrm{~mm} \leq l_{d} \leq 160 \mathrm{~mm}$.

Figs. 6-7 show the variation of bond strength test results with temperature for air and water cooling procedures and embedment length between $30 \mathrm{~mm}$ to $160 \mathrm{~mm}$. Fig. 6 makes comparison the proposed relationship for bond strength with $30 \mathrm{~mm}<l_{d} \leq 100 \mathrm{~mm}, 100 \mathrm{~mm}<l_{d} \leq 160 \mathrm{~mm}$, and $30 \mathrm{~mm} \leq l_{d} \leq 160 \mathrm{~mm}$ and air cooling condition at different temperatures against published experimental test. The bond strength with $30 \mathrm{~mm}<l_{d} \leq 100 \mathrm{~mm}$ condition typically loses $26 \%$ of its original compressive strength when heated to $300^{\circ} \mathrm{C}, 56 \%$ at $600^{\circ} \mathrm{C}$, and $78 \%$ at $800^{\circ} \mathrm{C}$. For bond strength with $100 \mathrm{~mm}<l_{d} \leq 160 \mathrm{~mm}$ condition typically loses $19 \%$ of its original compressive strength when heated to $300^{\circ} \mathrm{C}, 56 \%$ at $600^{\circ} \mathrm{C}$, and $90 \%$ at $800^{\circ} \mathrm{C}$, and finally for whole range $30 \mathrm{~mm} \leq l_{d} \leq 160 \mathrm{~mm}$ the bond strength loses $24 \%$ of its original compressive strength when heated to $300^{\circ} \mathrm{C}, 61 \%$ at $600^{\circ} \mathrm{C}$, and $92 \%$ at $800^{\circ} \mathrm{C}$.

Moreover, Fig. 7 makes comparison the proposed relationship for bond strength with $30 \mathrm{~mm}<$ $l_{d} \leq 100 \mathrm{~mm}, 100 \mathrm{~mm}<l_{d} \leq 160 \mathrm{~mm}$, and $30 \mathrm{~mm} \leq l_{d} \leq 160 \mathrm{~mm}$ and water cooling condition at 


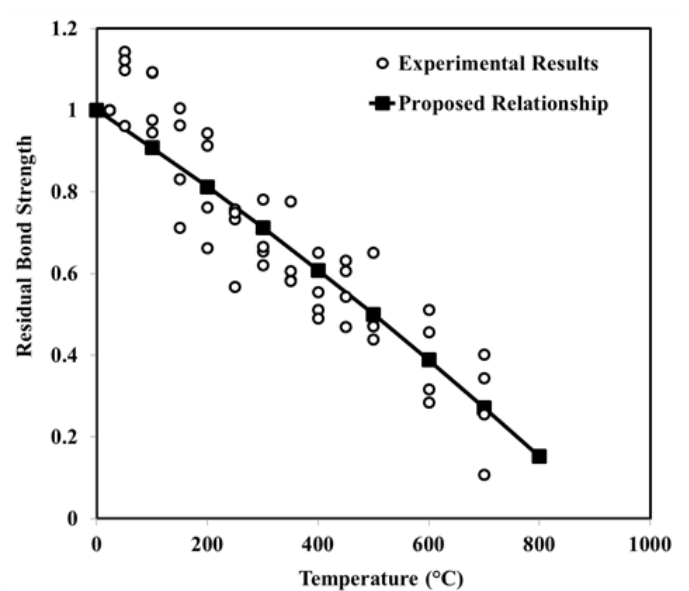

(a)

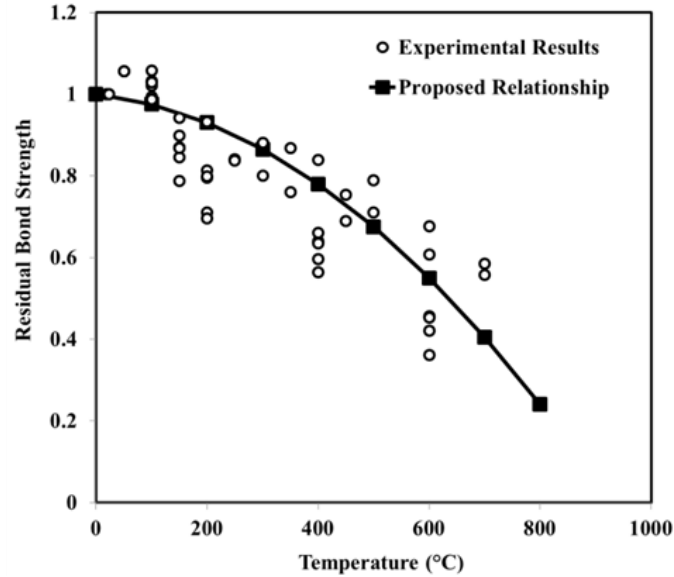

(b)

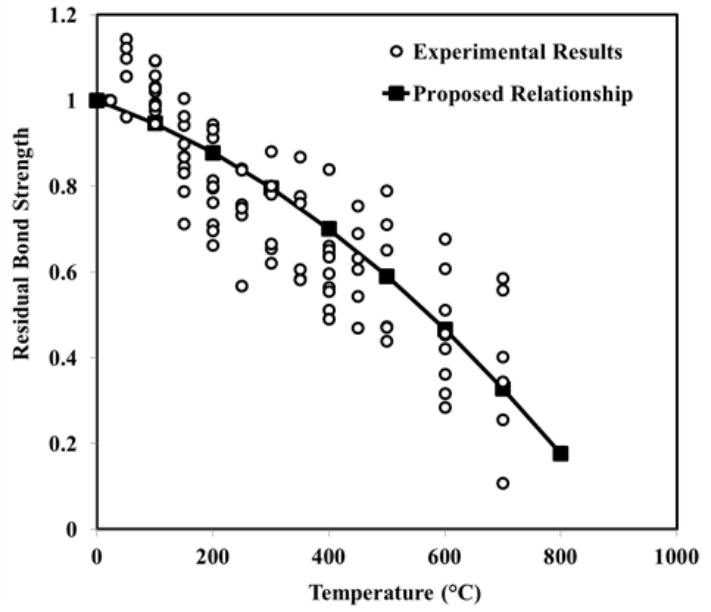

(c)

Fig. 7 Comparison between the water cooling condition proposed relationship for bond strength at different temperatures against experimental results database with (a) $30 \mathrm{~mm}<l_{d} \leq$ $100 \mathrm{~mm}$, (b) $100 \mathrm{~mm}<l_{d} \leq 160 \mathrm{~mm}$, and (c) $30 \mathrm{~mm} \leq l_{d} \leq 160 \mathrm{~mm}$

different temperatures against published experimental test. The bond strength with $30 \mathrm{~mm}<l_{d} \leq$ $100 \mathrm{~mm}$ condition typically loses $29 \%$ of its original compressive strength when heated to $300^{\circ} \mathrm{C}$, $61 \%$ at $600^{\circ} \mathrm{C}$, and $85 \%$ at $800^{\circ} \mathrm{C}$. For bond strength with $100 \mathrm{~mm}<l_{d} \leq 160 \mathrm{~mm}$ condition typically loses $13 \%$ of its original compressive strength when heated to $300^{\circ} \mathrm{C}, 45 \%$ at $600^{\circ} \mathrm{C}$, and $76 \%$ at $800^{\circ} \mathrm{C}$, and finally for whole range $30 \mathrm{~mm} \leq l_{d} \leq 160 \mathrm{~mm}$ the bond strength loses $20 \%$ of its original compressive strength when heated to $300^{\circ} \mathrm{C}, 53 \%$ at $600^{\circ} \mathrm{C}$, and $82 \%$ at $800^{\circ} \mathrm{C}$.

\section{Bond strength- compressive strength relationship at elevated temperature}

With the increase of temperature residual compressive strength and residual bond strength losses were observed. As it can be seen briefly from the graphics (Fig. 8), the bond strengths of 
specimens increase with the increase of compressive strength, for both concrete type and for all embedment lengths. So it can be concluded that there is a linear relationship between compressive strength and bond strength of concrete-steel bars. In this study, the relationship proposed for the conventional concrete are based on regression analyses using existing experimental database expressed as Eq. (10). In the Eq. (10), $\tau_{\max , 20}$ parameter can be calculated by using Eqs. (6)-(7) that is covered plain and deformed rebar and $f_{c T}^{\prime} / f_{c}^{\prime}$ can be calculated by using Eqs. (1)-(5) that is covered NSC, HSC, CAC, and LAC.

$$
\frac{\tau_{\max , T}}{\tau_{\max , 20}}=\left\{\begin{array}{cc}
1.0538\left(f_{c T}^{\prime} / f_{c}^{\prime}\right)-0.0255 & 30 \mathrm{~mm}<d_{b} \leq 100 \mathrm{~mm} \\
0.5273\left(f_{c T}^{\prime} / f_{c}^{\prime}\right)+0.4169 & 100 \mathrm{~mm}<d_{b} \leq 160 \mathrm{~mm} \\
0.7905\left(f_{c T}^{\prime} / f_{c}^{\prime}\right)+0.1862 & 30 \mathrm{~mm} \leq d_{b} \leq 160 \mathrm{~mm}
\end{array}\right\} \quad 100^{\circ} \mathrm{C} \leq T \leq 800^{\circ} \mathrm{C}
$$

Fig. 8 makes comparison the proposed bond strength-compressive strength relationship with 30 $\mathrm{mm}<l_{d} \leq 100 \mathrm{~mm}, 100 \mathrm{~mm}<l_{d} \leq 160 \mathrm{~mm}$, and $30 \mathrm{~mm} \leq l_{d} \leq 160 \mathrm{~mm}$ at different temperatures against experimental results database.

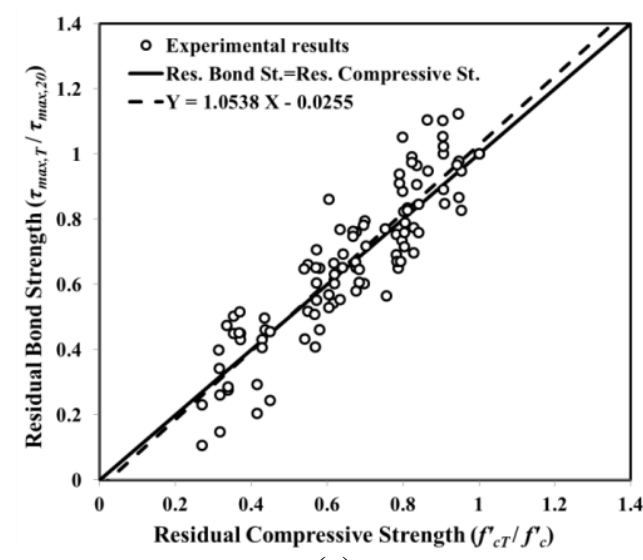

(a)

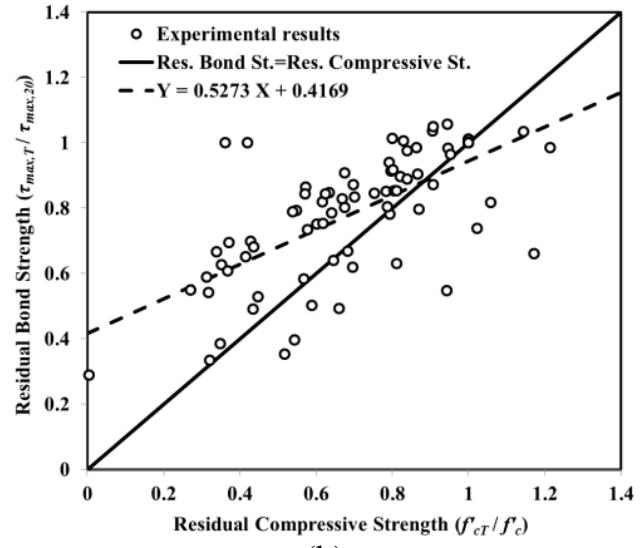

(b)

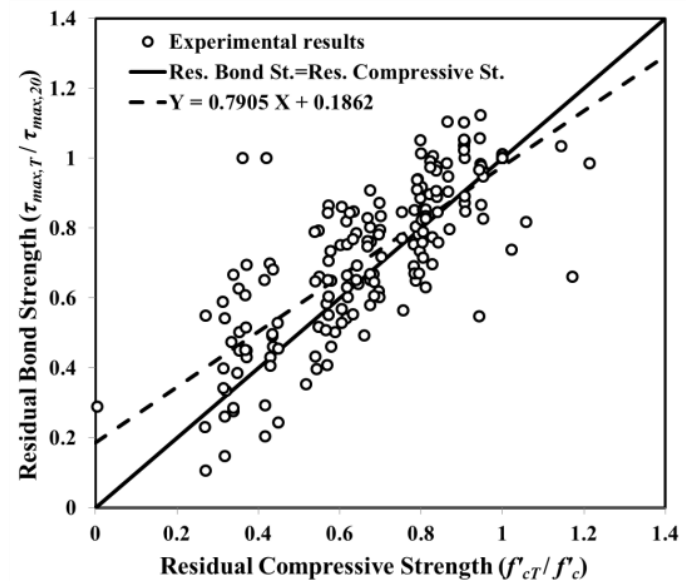

(c)

Fig. 8 Residual bond strength- residual compressive strength relationship for (a) $30 \mathrm{~mm}<l_{d} \leq$ $100 \mathrm{~mm}$, (b) $100 \mathrm{~mm}<l_{d} \leq 160 \mathrm{~mm}$, and (c) $30 \mathrm{~mm} \leq l_{d} \leq 160 \mathrm{~mm}$ 
Table 3 Analytical bond stress-slip models

\begin{tabular}{|c|c|c|c|c|c|c|c|}
\hline \multicolumn{2}{|c|}{ Reference } & \multicolumn{5}{|c|}{ Bond stress-slip equation } & Units \\
\hline \multicolumn{2}{|c|}{ Barbosa (2001) } & \multicolumn{5}{|c|}{$\begin{array}{l}\tau=19.36 s^{0.51}\left(f_{c}^{\prime}<50 \mathrm{MPa}\right) \\
\tau=32.58 s^{0.48}\left(f_{c}^{\prime} \geq 50 \mathrm{MPa}\right)\end{array}$} & SI units \\
\hline \multicolumn{2}{|c|}{$\begin{array}{l}\text { CEB-FIP (1999), } \\
\text { Huang et al. (1996) } \\
\text { and Harajli et al. } \\
\text { (1995) }\end{array}$} & $\tau=$ & \multicolumn{2}{|c|}{$\begin{array}{c}\tau_{\max }\left(s / s_{1}\right)^{\alpha} \\
\tau_{\max }\end{array}$} & 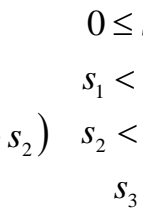 & $\left.\begin{array}{l}\begin{array}{l}s_{1} \\
\leq \\
\leq \\
\leq \\
\leq\end{array} \\
s\end{array}\right\}$ & SI units \\
\hline $\begin{array}{l}\text { CEB-FIP } \\
(1999)\end{array}$ & $\begin{array}{l}\text { Confined } \\
\text { concrete }\end{array}$ & $\begin{array}{l}\text { Unconfined } \\
\text { concrete }\end{array}$ & $\begin{array}{l}\text { Huang et } \\
\text { al. (1996) }\end{array}$ & $\begin{array}{c}\text { High } \\
\text { strength } \\
\text { concrete }\end{array}$ & $\begin{array}{l}\text { Normal } \\
\text { strength } \\
\text { concrete }\end{array}$ & $\begin{array}{l}\text { Harajli et al. } \\
\text { (1995) }\end{array}$ & Concrete \\
\hline$s_{I}(\mathrm{~mm})$ & 1.0 & 0.6 & $s_{I}(\mathrm{~mm})$ & 0.5 & 1 & $s_{1}(\mathrm{~mm})$ & $\begin{array}{c}0.15 \\
\text { Distance } \\
\text { between } \\
\text { ribs } \\
0.35\end{array}$ \\
\hline$s_{2}(\mathrm{~mm})$ & 3.0 & 0.6 & $s_{2}(\mathrm{~mm})$ & 1.5 & 3 & $s_{2}(\mathrm{~mm})$ & $\begin{array}{l}\text { Distance } \\
\text { between } \\
\text { ribs }\end{array}$ \\
\hline$s_{3}(\mathrm{~mm})$ & $\begin{array}{l}\text { Distance } \\
\text { between } \\
\text { ribs }\end{array}$ & 1.0 & $s_{3}(\mathrm{~mm})$ & $\begin{array}{l}\text { Distance } \\
\text { between } \\
\text { ribs }\end{array}$ & $\begin{array}{l}\text { Distance } \\
\text { between } \\
\text { ribs }\end{array}$ & $s_{3}(\mathrm{~mm})$ & $\begin{array}{l}\text { Distance } \\
\text { between } \\
\text { ribs }\end{array}$ \\
\hline$\alpha$ & 0.4 & 0.4 & $\alpha$ & 0.3 & 0.4 & $\alpha$ & 0.3 \\
\hline$\tau_{\max }$ & $2.5 \sqrt{f_{c}^{\prime}}$ & $2.0 \sqrt{f_{c}^{\prime}}$ & $\tau_{\max }$ & $0.4 f_{c m}$ & $0.4 f_{c m}$ & $\tau_{\max }$ & $2.57 \sqrt{f_{c}^{\prime}}$ \\
\hline$\tau_{u}$ & $0.4 \tau_{\max }$ & $0.15 \tau_{\max }$ & $\tau_{u}$ & $0.4 \tau_{\max }$ & $0.4 \tau_{\max }$ & $\tau_{u}$ & $0.9 \sqrt{f_{c}^{\prime}}$ \\
\hline
\end{tabular}

\section{Bond stress-slip prediction relationship at elevated temperature}

In the analysis of reinforced concrete structures, the bond action between steel bars and concrete is often viewed as a bond-slip relationship. This relationship expresses the local bond stress at any location along a bar as a function of the local slip. Numerous bond-slip relationships have been proposed and formulated. However, given that bond-slip relationships are impacted by various factors (CEB 1982) that vary across bond tests, these proposed models are different (Morita and Fujii 1985). For example, in pullout tests, bond-slip relationships obtained from extremely short specimens are different from those obtained from longer ones (Yamao et al. 1984). Even in the same specimen, the bond-slip relationship varies with the location along the bar if the free end slip exists (Chou et al. 1983). Table 3 shows several bond stress-slip prediction models (Barbosa 2001, CEB-FIP 1999, Huang et al. 1996, Harajli et al. 1995) described in the literature. According to Table 3, three of these models are based on and similar to the main curve of bond stress-slip, although the influencing parameters are different. In this study, the main curve is similar to the CEB-FIP (1999), Huang et al. (1996), and Harajli et al. (1995) models but the $\tau_{\max , T}$ parameter for different types of concrete and cooling condition are different. The proposed bond stress-slip prediction relationship at elevated temperature in this study is shown in Eqs. (11)-(15). 


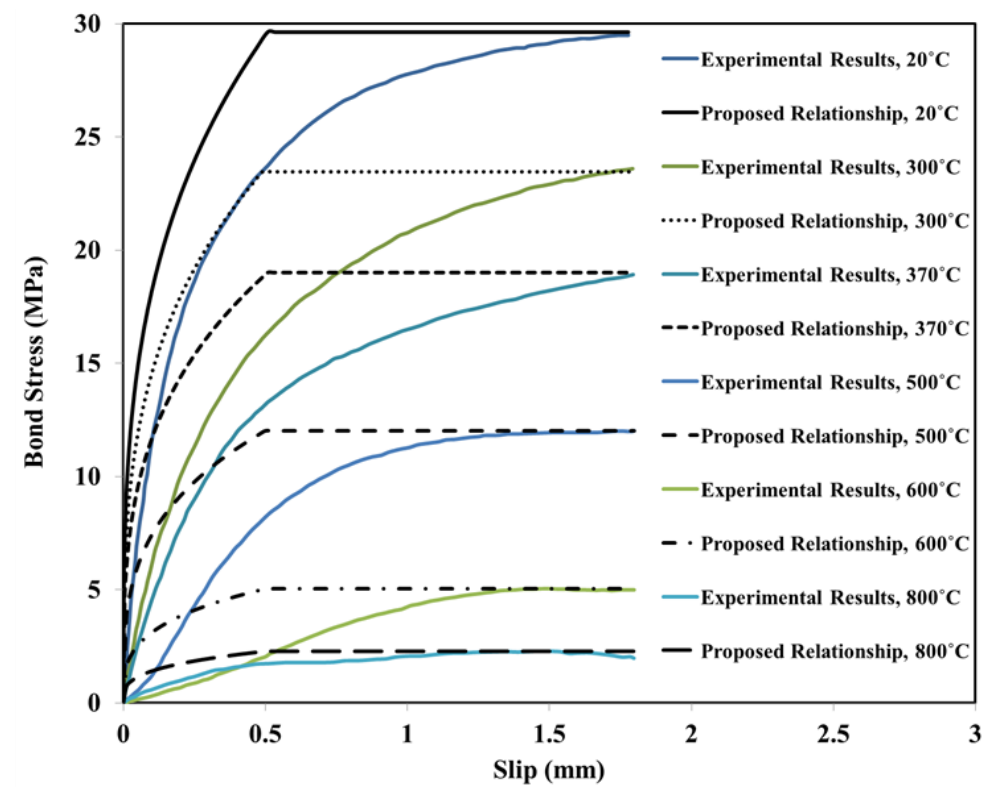

Fig. 9 Comparison between bond stress-slip proposed relationship with experimental results of Diederichs and Schneider (1981)

$$
\begin{gathered}
\tau_{b, T}=\left\{\begin{array}{cc}
\tau_{\max , T}\left(s / s_{1}\right)^{\alpha} & 0 \leq s \leq s_{1} \\
\tau_{\max , T} & s_{1}<s \leq s_{2} \\
\tau_{\max , T}-\left(\tau_{\max , T}-\tau_{u, T}\right)\left(s-s_{2} / s_{3}-s_{2}\right) & s_{2}<s \leq s_{3} \\
\tau_{u, T}=0.4 \tau_{\max , T} & s_{3}<s
\end{array}\right\} \\
s_{1}(\mathrm{~mm})=\left\{\begin{array}{lc}
0.5 \mathrm{~mm} & H S C \\
1.0 \mathrm{~mm} & \text { NSC } \\
1.0 \mathrm{~mm} & \text { Confinedconcrete } \\
0.6 \mathrm{~mm} & \text { Unconfinedconcrete }
\end{array}\right\} \\
s_{2}(\mathrm{~mm})=\left\{\begin{array}{cc}
2.0 \mathrm{~mm} & \text { HSC } \\
3.0 \mathrm{~mm} & \text { NSC } \\
3.0 \mathrm{~mm} & \text { Confinedconcrete } \\
0.6 \mathrm{~mm} & \text { Unconfinedconcrete }
\end{array}\right\}
\end{gathered}
$$

$$
s_{3}(\mathrm{~mm})=\left\{\begin{array}{cc}
\text { Distance between ribs } & H S C \\
\text { Distance between ribs } & \text { NSC } \\
\text { Distance between ribs } & \text { Confinedconcrete } \\
1.0 \mathrm{~mm} & \text { Unconfinedconcrete }
\end{array}\right\}
$$




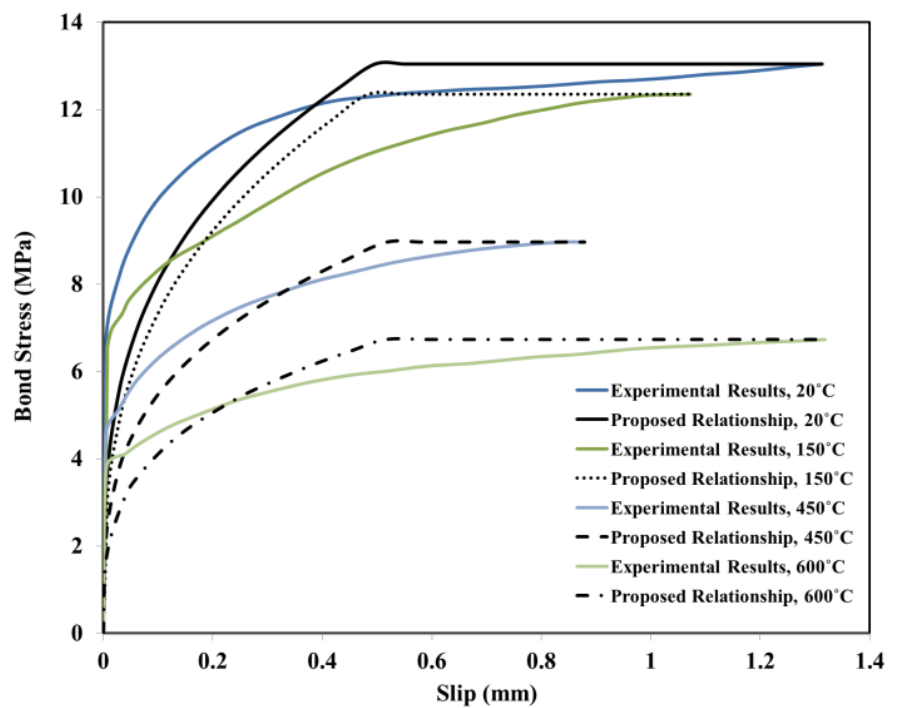

Fig. 10 Comparison between bond stress-slip proposed relationship with experimental results of Morley and Royles (1983)

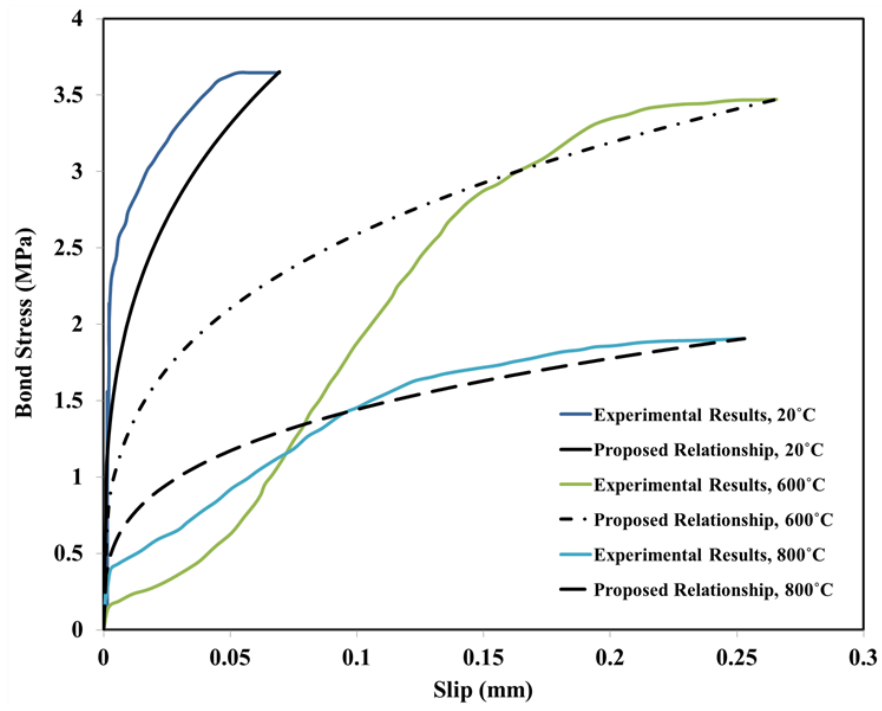

Fig. 11 Comparison between bond stress-slip proposed relationship with experimental results of Haddad and Shannis (2004)

$$
\tau_{\max , T}=\left\{\begin{array}{cc}
\text { Equation (8) } & \text { Air cooling } \\
\text { Equation (9) } & \text { Water cooling } \\
\text { Equations (10 and 1) } & \text { related to } \mathrm{f}_{\mathrm{cT}}^{\prime}-\text { for NSC } \\
\text { Equations (10 and 2 - 3) } & \text { related to } \mathrm{f}_{\mathrm{cT}}^{\prime}-\text { for HSC } \\
\text { Equations (10 and 4) } & \text { related to } \mathrm{f}_{\mathrm{cT}}^{\prime}-\text { for CAC } \\
\text { Equations (10 and 5) } & \text { related to } \mathrm{f}_{\mathrm{cT}}^{\prime}-\text { for LAC }
\end{array}\right\}
$$




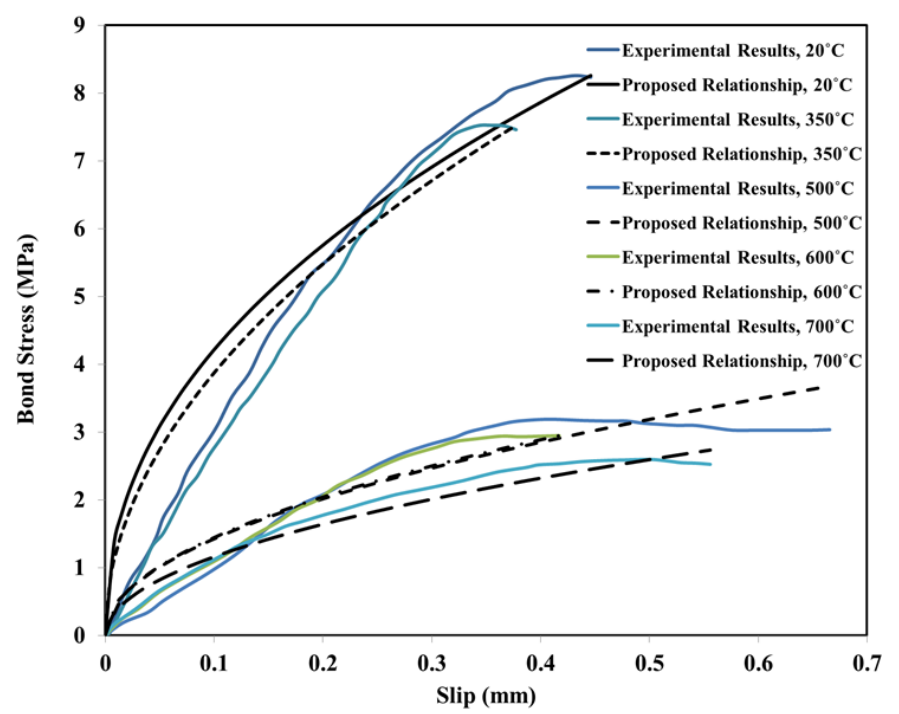

Fig. 12 Comparison between bond stress-slip proposed relationship with experimental results of Haddad et al. (2008)

Figs. 9-12 illustrate the capability of proposed bond stress-slip prediction relationship at elevated temperature compared with the findings of Diederichs and Schneider (1981), Morley and Royles (1983), Haddad and Shannis (2004), Haddad et al. (2008). The proposed relationships fit the experimental results at elevated temperature well.

\section{Conclusions}

The major conclusions reached on the basis of the present work are:

1. The proposed compressive strength relationships at elevated temperatures are useful for prediction of NSC, HSC, CAC, and LAC's compressive strength.

2. In this study the proposed bond strength relationships at elevated temperatures are related to compressive strength of NSC, HSC, CAC, and LAC at elevated temperatures.

3. The proposed bond strength relationships at elevated temperatures (between $100^{\circ} \mathrm{C}$ to $800^{\circ} \mathrm{C}$ ) are useful for air and water cooling procedures.

4. The proposed bond strength relationships at elevated temperatures are related to the following parameters the diameter of the steel bar, embedded length of the steel bar, compressive strength of the concrete, and concrete cover by using bond strength relationships at ambient temperature.

5. The proposed relationships for the compressive and bond strength of different types of concrete at elevated temperature are in good reasonable agreement with the experimental results.

6. The proposed compressive and bond strength relationships are simple and reliable for modeling the compressive and bond behavior of NSC and HSC at elevated temperatures. Also, using these relationships in the finite element method (FEM) is more simple and suitable.

7. The predicted values of the proposed bond stress-slip model using proposed bond strength models verified that this model can predict good the bond stress-slip curve of NSC and HSC in the 
various conditions (such as different bar pullout positions, different ages of concrete, different compressive strength, and different bar diameters).

\section{References}

Abrams, M.S. (1971), "Compressive strength of concrete at temperatures to $1600^{\circ} \mathrm{F}$ ", Temperature and Concrete, Detroit (MI), American Concrete Institute, Special Publication, SP-25.

ACI 318 (2008), "Building code requirements for structural concrete and commentary", American Concrete Institute.

Ahmed, A.E., Al-Shaikh, A.H. and Arafat, T.I. (1992), "Residual compressive and bond strengths of limestone aggregate concrete subjected to elevated temperatures", Mag. Concrete Res., 44(159), 117-125.

Aslani, F. and Bastami, M. (2011), "Constitutive models and relationships for normal and high strength concrete at elevated temperatures", ACI Mater. J., 108(4), 355-364.

Aslani, F. and Nejadi, S. (2012), "Bond behavior of reinforcement in conventional and self-compacting concrete", Adv. Struct. Eng., 15(12), 2033-2051.

Aslani, F. and Samali, B. (2013a), "Constitutive relationships for steel fiber reinforced concrete at elevated temperatures", Fire Tech., doi: 10.1007/s10694-012-0322-5.

Aslani, F. and Samali, B. (2013b), "High strength polypropylene fibre reinforcement concrete at high temperature", Fire Tech., doi: 10.1007/s10694-013-0332-y.

Aslani, F. and Samali, B. (2013c), "Constitutive relationships for self-compacting concrete at elevated temperatures", Mater. Struct., doi: 10.1617/s11527-013-0187-1.

Barbosa, M.T.G. (2001), "Evaluation of the behavior of the bond in ordinary and high strength concrete", Doctoral Thesis, COPPE/UFRJ. (in Portuguese)

Bazant, Z.P. and Kaplan, M.F. (1996), "Concrete at high temperatures", Longman Group Limited.

Bingöl, A.F. and Gül, R. (2009), "Residual bond strength between steel bars and concrete after elevated temperatures", Fire Saf. J., 44, 854-859

Castillo, C. and Durrani, A.J. (1990). "Effect of transient high temperature on high strength concrete", ACI Mater. J., 87(1), 47-53.

Carrasquillo, R., Nilson, A. and Slate, F. (1981), "Properties of high strength concrete subject to short-term loads", ACI J., 78(3), 171-178.

CEB-FIP (1999), "Structural Concrete", Bulletin No. 1, Paris, France.

CEB (1982), Bulletin D'Information No 151, "Bond action and bond behaviour of reinforcement (State-ofthe- art report)", CEB, Paris, France, 153.

Chang, Y.F., Chen, Y.H., Sheu, M.S. and Yao, G.C. (2006), "Residual stress-strain relationship for concrete after exposure to high temperatures", Cement Concrete Res., 36, 1999-2005.

Chou, L., Niwa, J. and Okamura, H. (1983), "Bond model for deformed bars embedded in massive concrete", Proceedings of 2nd JCI Colloquium on Shear Analysis of RC Structures, JCI, 45-52. (in Japanese)

Diederichs, U. and Schneider, U. (1981), "Bond strength at high temperatures", Mag. Concrete Res., 33(115), 75-84.

Diederichs, U., Jumppanen, U.M. and Penttala, V. (1988), "Material properties of high strength concrete at elevated temperature", IABSE 13thCongress, Helsinki.

Fib Bulletin 46 (2008), "Fire design of concrete structures - structural behaviour and assessment", State-ofArt Report, Chapter 6, Expertise and Assessment of Materials and Structures after Fire.

Furumura, F., Abe, T. and Shinohara, Y. (1995), "Mechanical properties of high strength concrete at high temperatures", Proceedings of the Fourth Weimar Workshop on High Performance Concrete: Material Properties and Design, Hochschule fur Architekture and Bauwesen (Hab), Weimar, Germany.

Haddad, R.H. and Shannis, L.G. (2004), "Post-fire behavior of bond between high strength pozzolanic concrete and reinforcing steel", Constr. Build. Mater., 18, 425-435. 
Haddad, R.H., Al-Saleh, R.J. and Al-Akhras, N.M. (2008), "Effect of elevated temperature on bond between steel reinforcement and fiber reinforced concrete", Fire Saf. J., 43, 334-343.

Harajli, M.H., Hout, M. and Jalkh, W. (1995), "Local bond stress-slip behaviour of reinforcing bars emlbedded in plain and fibre concrete", ACI Mater. J., 92(4), 343-353.

Hertz, K. (1982), "The anchorage capacity of reinforcing bars at normal and high temperatures", Mag. Concrete Res., 35(121), 213-220.

Huang, Z., Engström, B. and Magnusson, J. (1996), "Experimental investigation of the bond and anchorage behaviour of deformed bars in high strength concrete", Report 94:4, Chalmers University of Technology.

Kasami, H., Okuno, T. and Yamane, S. (1975), "Properties of concrete exposed to sustained elevated temperature", Transactions of the Third International Conference on Structural Mechanics in Reactor Technology, London, September.

Milovanovf, A. and Salmanov, G.D. (1954), "The influence of high temperatures upon the properties of reinforcing steels and upon bond strength between reinforcement and concrete", Issledovanija po zharoupornym betonu i zhelezobetonu, 203-223. (in Russian)

Malhotra, V.M. (1975), "Evaluation of the pullout test to determine strength in-situ concrete", RILEM Pub SARL, 8(43), 19-31.

Morita, S. and Fujii, S. (1985), "Bond-slip models in finite element analysis", Proceeding of Japan-US Seminar on Finite Element Analysis of Reinforced Concrete Structures, Tokyo.

Poon, C.S., Azhar, S., Anson, M. and Wong, Y.L. (2003), "Performance of Metakaolin concrete at elevated temperatures", Cement Concrete Compos., 25(1), 83-89.

Reichel, V. (1978), "How wire affects steel-to-concrete bond", Build. Res. Practice, 6(3), 176- 1Xh.

Richards, O. (1977), "Pullout strength of concrete reproducibility and accuracy of mechanical tests", ASTM STP REP. No. 626, American Society for Testing and Materials, Philadelphia.

Royles, R., Morley, P. and Khan, M.R. (1982), "The behavior of reinforced concrete at elevated temperatures with particular reference to bond strength", Ed. Bartos, P., Proceedings of Conference on Bond in Concrete, Paisley, Scotland.

Royles, R. and Morley, P. (1983), "Response of the bond in reinforced concrete to high temperatures", Mag. Concrete Res., 35(123), 67-74.

Sancak, E., Sari, D. and Simsek, O. (2008), "Effects of elevated temperature on compressive strength and weight loss of the light-weight concrete with silica fume and super plasticizer", Cement Concrete Compos., 30(8), 715-721.

Savva, A., Manita, P. and Sideris, K.K. (2005), "Influence of elevated temperatures on the mechanical properties of blended cement concretes prepared with limestone and siliceous aggregates", Cement Concrete Compos., 27, 239-248.

Schneider, U. (1985), "Properties of materials at high temperatures - concrete", RILEM - Committee 44 PHT, University of Kassel, Kassel.

Skramtajew, B.G. (1983), "Determining concrete strength for control of concrete in structures", ACI J. Proc., 34(1), 205-304.

Stone, W.C. and Giza, B.J. (1987), "The effect of geometry and aggregate on the reliability of the pullout test", Concrete Int., 7(2), 27-36.

Stone, W.C. and Carino, N.J. (1983), "Deformation and failure in large-scale pullout tests", ACI J. Proc., 80(6), 501-513.

Yamao, H., Chou, L. and Niwa, J. (1984), "Experimental study on bond stress-slip relationship", Proceedings of JSCE, No. 343, 219-228. (in Japanese)

Yi, S.T., Yang, E.I. and Choi, J.Ch. (2006), "Effect of specimen sizes, specimen shapes, and placement directions on compressive strength of concrete", Nucl. Eng. Des., 235, 115-127. 